\title{
Angiopoietin-1: an early biomarker of diabetic nephropathy?
}

\author{
Alexandra E. Butler ${ }^{1 *} \mathbb{D}$, Ahmed Al-Qaissi ${ }^{2,3}$, Thozhukat Sathyapalan ${ }^{2}$ and Stephen L. Atkin ${ }^{1}$
}

Keywords: Type 2 diabetes, Diabetic kidney disease, Biomarkers, Proteomics

Letter to the Editor

Diabetic kidney disease (DKD) with progression to end-stage renal disease (ESRD) is a much-feared diabetes complication. Early recognition is key to preventing decline in renal function and, hence, biomarkers to stratify risk of functional decline have been actively sought. In a recent publication, plasma proteomic analysis was performed using the SOMASCAN platform in two longitudinal exploratory studies of type 1 (T1D) and type 2 diabetes (T2D) patients with chronic kidney disease (CKD) stage-3 to identify candidate protective biomarkers against progressive renal function decline/progression to ESRD, findings validated in a T1D patient cohort with normal renal function [1]. Their findings distilled down to three proteins that showed a strong, additive protective effect against decline in renal function: angiopoeitin-1 (ANGPT1), tumor necrosis factor receptor superfamily 12 (TNFRSF12) and fibroblast growth factor 20 (FGF20) [1].

Glucose variability, potentiating hyper- or hypoglycemia, positively associates with both micro- and macrovascular diabetes complications [2] and may be an independent risk factor, seen by glucose variability accelerating renal injury in rats [3]. Stringent therapeutic regimens aimed at maintaining normoglycemia in diabetes patients have increase the frequency of hypoglycemic episodes [4].

*Correspondence: aeb91011@gmail.com; abutler@rcsi.com

1 Department of Research, Royal College of Surgeons of Ireland, PO Box 15503, Adliya, Bahrain

Full list of author information is available at the end of the article
We hypothesized that the protective biomarkers of renal function identified in the Joslin study [1] may be elevated early in T2D and be affected by glucose excursions including a hypoglycemic insult.

We performed a case-controlled study in 23 T2D and 23 control age-matched Caucasian subjects. Following a 10-h fast, each subject underwent a hyperinsulinemic clamp, as previously described [5]. Baseline plasma glucose in the T2D cohort was $7.6 \pm 0.4 \mathrm{mmol} / \mathrm{L}$ $(136.8 \pm 7.2 \mathrm{mg} / \mathrm{dl})$; glucose was normalized to $4.5 \pm 0.1 \mathrm{mmol} / \mathrm{L}(81 \pm 1.2 \mathrm{mg} / \mathrm{dl})$ for $1-\mathrm{h}$. In the control cohort, plasma glucose was maintained at the baseline level of $4.9 \pm 0.1 \mathrm{mmol} / \mathrm{L}(88.2 \pm 1.8 \mathrm{mg} / \mathrm{dl})$ during this normalization period. Thereafter, glucose was lowered to hypoglycemic levels, where blood glucose (BG) levels were $2.0 \pm 0.03 \mathrm{mmol} / \mathrm{L}$ in T2D and $1.8 \pm 0.05 \mathrm{mmol} / \mathrm{L}$ in controls. Plasma samples were collected at baseline, at glucose normalization (T2D only), at hypoglycemia and during the post-hypoglycemia follow up period $(0.5,1,2$, 4 and 24-h), as previously described [5].

Using the same Slow Off-rate Modified Aptamer (SOMA)-scan measurement (SOMAscan) proteomics platform as used by Dom et al. [1], we determined levels of the three validated renal protective proteins: ANGPT1, TNFSF12 and FGF20 at these timepoints.

The T2D cohort studied here had a relatively short disease duration ( $4.5 \pm 2.2$ years) with no diabetic complications and a normal eGFR, though BMI was increased versus controls $(\mathrm{p}=0.001)$.

Protein levels throughout the study timecourse are shown in Fig. 1. At baseline, plasma FGF20 was higher in controls $(\mathrm{p}<0.01)$, ANGPT1 was higher in T2D

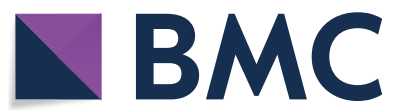

(c) The Author(s) 2021. Open Access This article is licensed under a Creative Commons Attribution 4.0 International License, which permits use, sharing, adaptation, distribution and reproduction in any medium or format, as long as you give appropriate credit to the original author(s) and the source, provide a link to the Creative Commons licence, and indicate if changes were made. The images or other third party material in this article are included in the article's Creative Commons licence, unless indicated otherwise in a credit line to the material. If material is not included in the article's Creative Commons licence and your intended use is not permitted by statutory regulation or exceeds the permitted use, you will need to obtain permission directly from the copyright holder. To view a copy of this licence, visit http://creativecommons.org/licenses/by/4.0/. The Creative Commons Public Domain Dedication waiver (http://creativecommons.org/publicdomain/zero/1.0/) applies to the data made available in this article, unless otherwise stated in a credit line to the data. 


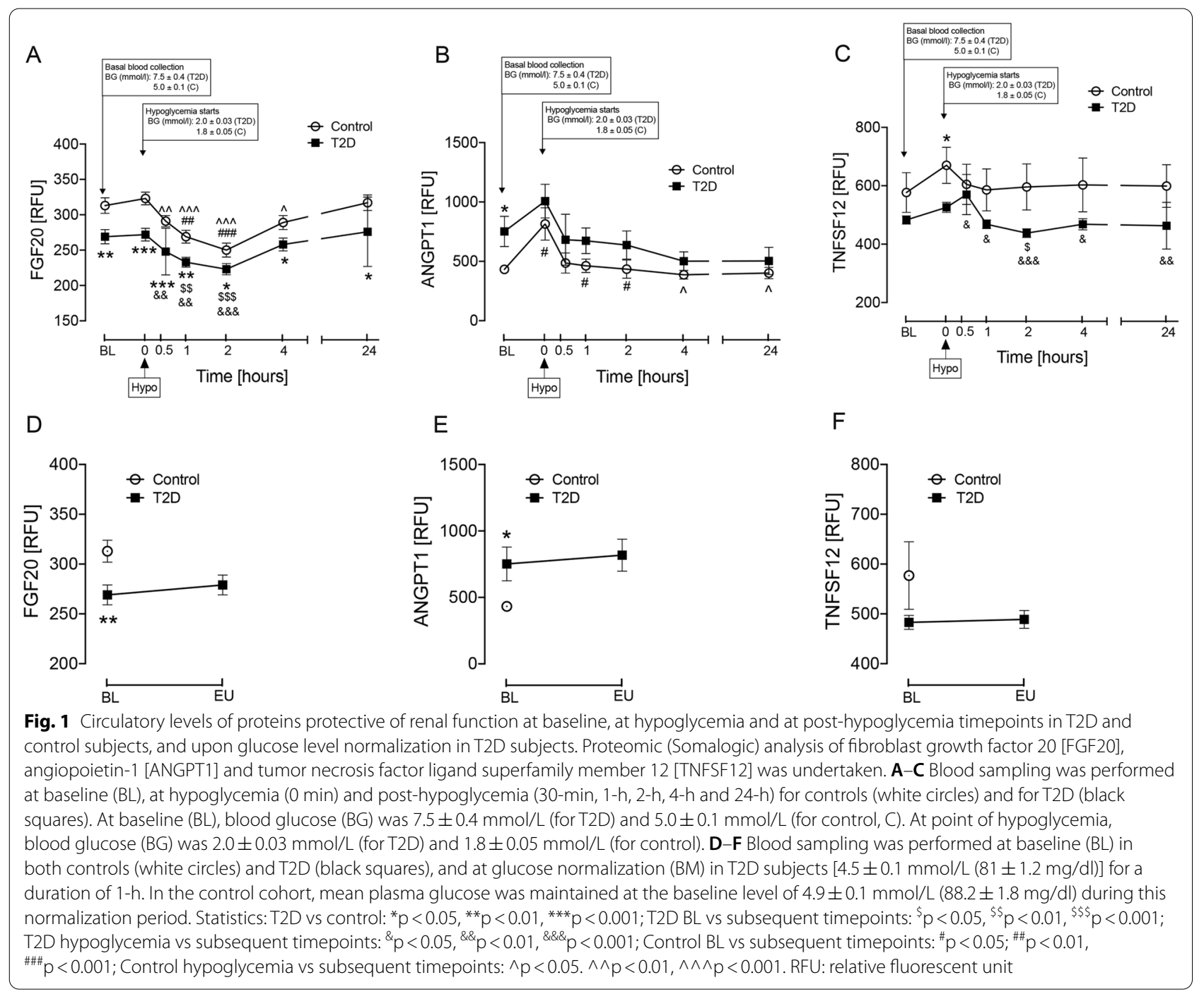

$(\mathrm{p}<0.05)$ whilst there was a trend to lower TNFSF12 levels in T2D (Fig. 1A-C).

At euglycemia in T2D there was no difference in FGF20, ANGPT1 or TNFSF12 (Fig. 1D-F).

At hypoglycemia, FGF20 remained higher in controls $(\mathrm{p}<0.001)$; ANGPT1 levels increased more in controls than T2D, achieving similar levels in both cohorts $(\mathrm{p}=\mathrm{ns})$. Likewise, levels of TNFSF12 increased more in controls than in $\mathrm{T} 2 \mathrm{D}$, resulting in a significant difference between cohorts $(p<0.05)$.

During the post-hypoglycemia follow-up period, FGF20 remained consistently higher in controls (30-min and 2-h: $\mathrm{p}<0.001 ; 1-\mathrm{h}: \mathrm{p}<0.01 ; 4-$ and 24-h, $\mathrm{p}<0.05)$. ANGPT1 and TNFSF12 levels were not different between cohorts at any post-hypoglycemia timepoint.

Interestingly, when glucose levels were normalized in the T2D cohort (Fig. 1D-F), protein levels were unchanged, indicating that glucose variability did not affect the circulating protein levels.

In early diabetes with normal eGFR, plasma ANGPT1 is elevated, suggesting that this may be an early marker of renal dysfunction, whilst TNFSF12 and FGF20 are not. This may indicate that ANGPT1 is an early biomarker and, upon diagnosis, should be measured and, if elevated, additional care taken to aggressively prevent renal disease. Post-diagnosis, should a subsequent increase in TNFSF12 and FGF20 occur, this may indicate progression of renal disease, even without overt changes in eGFR or an increased albumin:creatinine ratio, and would again justify aggressive preventative measures. Further, our results indicate that levels of ANGPT1, TNFSF12 and FGF20 are unaffected by glucose normalization in T2D and therefore not prone to variability in response to 
glucose fluctuations; therefore, fasting samples are not required.

Strengths of this study are use of the identical SOMAscan proteomics platform as in the reference paper [1], making our results directly comparable; the enrollment of a population of T2D with short duration of disease and without diabetes complications, who had a normal GFR and who were treatment naïve. Limitations include relatively small study numbers and that this was a homogeneous Caucasian population, so the results may not be applicable to other ethnic groups.

In conclusion, ANGPT1 may be the earliest biomarker of potential diabetes-related renal disease progression. This data suggests that prospective studies be undertaken to confirm or refute whether this reflects future clinical risk and would therefore impact clinical practice.

ClinicalTrials.gov NCT03102801. Date of registration April 6, 2017, retrospectively registered. https://clinicaltr ials.gov/ct2/show/NCT03102801?term $=$ NCT0310280 $1 \&$ draw $=2 \&$ rank $=1$

\section{Acknowledgements}

None.

\section{Authors' contributions}

AEB analyzed the data and wrote the manuscript. AA-Q performed the clinical studies. TS supervised clinical studies and edited the manuscript. SLA contributed to study design, data interpretation and the writing of the manuscript. All authors reviewed and approved the final version of the manuscript. SLA is the guarantor of this work. All authors read and approved the final manuscript.

\section{Funding}

No funding was received to perform this study.

\section{Availability of data and materials}

All the data for this study will be made available upon reasonable request to the corresponding author.

\section{Declarations}

Ethics approval and consent to participate

The trial was approved by the North West-Greater Manchester East Research Ethics Committee (REC number: 16/NW/0518), registered at www.clinicaltrials. gov (NCT03102801) on 06/04/2017 and conducted according to the Declaration of Helsinki. All participants provided written informed consent.

\section{Consent for publication}

All authors gave their consent for publication.

\section{Competing interests}

No authors have any conflict of interest or competing interests to declare.

\section{Author details}

${ }^{1}$ Department of Research, Royal College of Surgeons of Ireland, PO Box 15503 , Adliya, Bahrain. ${ }^{2}$ Academic Endocrinology, Diabetes and Metabolism, Hull York Medical School, Hull, UK. ${ }^{3}$ Leeds Medical School, Leeds, UK.

Received: 1 October 2021 Accepted: 4 October 2021

Published online: 13 October 2021

\section{References}

1. Md Dom ZI, Satake E, Skupien J, Krolewski B, O,Neil K, Willency JA, Dillon ST, Wilson JM, Kobayashi H, Ihara K, Libermann TA, Pragnell M, Duffin KL, Krolewski AS. Circulating proteins protect against renal decline and progression to end-stage renal disease in patients with diabetes. Sci Transl Med. 2021;13:eabd2699.

2. Frontoni S, Di Bartolo P, Avogaro A, Bosi E, Paolisso G, Ceriello A. Glucose variability: an emerging target for the treatment of diabetes mellitus. Diabetes Res Clin Pract. 2013;102:86-95.

3. Ying C, Zhou X, Chang Z, Ling H, Cheng X, Li W. Blood glucose fluctuation accelerates renal injury involved to inhibit the AKT signaling pathway in diabetic rats. Endocrine. 2016:53:81-96.

4. Action to Control Cardiovascular Risk in Diabetes Study. Gerstein HC, Miller ME, Byington RP, Goff Jr DC, Bigger JT, Buse JB, Cushman WC, Genuth S, Ismail-Beigi F, Grimm Jr RH, Probstfield JL, Simons-Morton DG, Friedewald WT. Effects of intensive glucose lowering in type 2 diabetes. N Engl J Med. 2008;358:2545-59.

5. Al-Qaissi A, Papageorgiou M, Deshmukh H, Madden LA, Rigby A, Kilpatrick ES, Atkin SL, Sathyapalan T. Effects of acute insulin-induced hypoglycaemia on endothelial microparticles in adults with and without type 2 diabetes. Diabetes Obes Metab. 2019;21:533-40.

\section{Publisher's Note}

Springer Nature remains neutral with regard to jurisdictional claims in published maps and institutional affiliations.
Ready to submit your research? Choose BMC and benefit from:
- fast, convenient online submission
- thorough peer review by experienced researchers in your field
- rapid publication on acceptance
- support for research data, including large and complex data types
- gold Open Access which fosters wider collaboration and increased citations
- maximum visibility for your research: over 100M website views per year
At BMC, research is always in progress.
Learn more biomedcentral.com/submissions 